\title{
Improving higher-order comprehension skills of Grade 3 learners in a second language at a quintile 2 school, in Cape Town, South Africa
}

\begin{tabular}{|c|c|}
\hline \multicolumn{2}{|c|}{$\begin{array}{l}\text { Authors: } \\
\text { Vuyokazi Fatyela }{ }^{1} \\
\text { Janet Condy }{ }^{1} \\
\text { Lawrence Meda }^{2} \\
\text { Heather Phillips }^{3}\end{array}$} \\
\hline \multicolumn{2}{|c|}{$\begin{array}{l}\text { Affiliations: } \\
{ }^{1} \text { Department of Literacy } \\
\text { Research Unit, Faculty of } \\
\text { Education, Cape Peninsula } \\
\text { University of Technology, } \\
\text { Cape Town, South Africa }\end{array}$} \\
\hline $\begin{array}{l}{ }^{2} \text { Research Dep } \\
\text { Faculty of Edu } \\
\text { University, Du } \\
\text { Arab Emirates }\end{array}$ & $\begin{array}{l}\text { artment, } \\
\text { cation, Zayed } \\
\text { bai, United }\end{array}$ \\
\hline \multicolumn{2}{|c|}{$\begin{array}{l}{ }^{3} \text { Research Department, } \\
\text { Faculty of Education, Cape } \\
\text { Peninsula University of } \\
\text { Technology, Cape Town, } \\
\text { South Africa }\end{array}$} \\
\hline \multicolumn{2}{|c|}{$\begin{array}{l}\text { Corresponding author: } \\
\text { Janet Condy, } \\
\text { condyj@cput.ac.za }\end{array}$} \\
\hline \multicolumn{2}{|c|}{$\begin{array}{l}\text { Dates: } \\
\text { Received: } 08 \text { Mar. } 2021 \\
\text { Accepted: } 19 \text { July } 2021 \\
\text { Published: } 14 \text { Sept. } 2021\end{array}$} \\
\hline \multicolumn{2}{|c|}{$\begin{array}{l}\text { How to cite this article: } \\
\text { Fatyela, V., Condy, J., Meda, L. } \\
\text { \& Phillips, H., 2021, } \\
\text { 'Improving higher-order } \\
\text { comprehension skills of } \\
\text { Grade } 3 \text { learners in a second } \\
\text { language at a quintile } 2 \\
\text { school, in Cape Town, South } \\
\text { Africa', Reading \& Writing } \\
\text { 12(1), a312. https://doi. } \\
\text { org/10.4102/rw.v12i1.312 }\end{array}$} \\
\hline \multicolumn{2}{|c|}{$\begin{array}{l}\text { Copyright: } \\
\text { (C) 2021. The Authors. } \\
\text { Licensee: AOSIS. This work } \\
\text { is licensed under the } \\
\text { Creative Commons } \\
\text { Attribution License. }\end{array}$} \\
\hline \multicolumn{2}{|l|}{ Read online: } \\
\hline 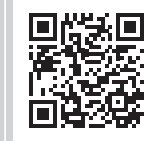 & $\begin{array}{l}\text { Scan this QR } \\
\text { code with your } \\
\text { smart phone or } \\
\text { mobile device } \\
\text { to read online. }\end{array}$ \\
\hline
\end{tabular}

Background: Developing higher-order comprehension skills of learners in primary schools is a challenge that faces many countries. South Africa is no exception. Primary school learners in South Africa have particularly low literacy and comprehension skills: many learners struggle to read for understanding. There is little published scholarship that focuses on developing the comprehension skills of Grade 3 learners in a second language. A lack of practical classroom knowledge in this area is what this article seeks to address.

Objectives: To improve the higher-order comprehension skills of Grade 3 learners in a second language.

Method: A qualitative approach, using a case study design, within an interpretivist paradigm was devised and deployed. Five struggling Grade 3 learners were purposively selected to participate in an intervention programme. Their parents or guardians and two current Grade 3 teachers were interviewed. Data were collected over a 10-week intervention programme. The first and last weeks were devoted to pre-testing and post-testing. The entire intervention lasted for 10 weeks.

Results: All the five Grade 3 learners showed significant improvements in their comprehension skills when comparing their pre-test and post-test scores.

Conclusion: The post-test scores revealed the importance of a structured intervention programme for improving the four comprehension skills highlighted. Mediation and scaffolding in the Zone of Proximal Development were employed while concurrently developing their cognitive, social and language skills.

Keywords: critical thinking; curriculum; Foundation Phase; higher-order thinking skills; Home Language.

\section{Introduction}

Developing higher-order comprehension skills of children in primary schools is a challenge that faces many countries. South Africa is no exception. Primary school learners in South Africa exhibit low literacy and comprehension skills: many learners struggle to read for understanding. These challenges are compounded by the fact that educators are not guided on literacy instruction. Taylor (2014) found that only six universities within South Africa provided undergraduate teachers with courses on literacy instruction and development, and the majority of tertiary institutions do not train their student educators to provide effective literacy instruction. Thus, the cycle of low literacy and comprehension skills among primary school learners continues to exist.

The present intervention was conducted to test whether it is possible, by means of a 10-week intervention, to raise the higher-order comprehension skills of learners in a South African urban 'township' school. The researcher was motivated by her own background as a Grade 3 teacher. She observed that comprehension is one of the most challenging skills in literacy education that isiXhosa home language (HL) learners in South Africa struggle with. The researcher's experience of teaching comprehension endorses the findings of Van der Berg et al. (2016) who state that 58\% of South African learners have not yet learnt to read for understanding in any language by the end of Grade 4. Learners cannot make sense of what they read. This reading barrier constrains performance in annual reading assessments.

Before 2016, the researcher found it challenging to teach comprehension skills to her isiXhosa learners, during her English class; they were seldom able to understand the higher-order thinking 
questions being asked of them in their texts and were unable to write appropriate answers in English. In an attempt to improve her comprehension teaching skills, she completed her Honours degree in 2016, and was introduced to a variety of pedagogical approaches to explicitly teach comprehension skills. In 2017, she registered for her master's degree, to continue this research focus where she linked theory and practice. She conducted a small research project while teaching nine specific higher-order thinking skills. The Western Cape Systemic Language results for this particular Grade 3 class, in which the researcher taught from 2016 to 2019, are shown below (Western Cape Education Department [WCED] 2016-2019):

Reading and Viewing: 2016 - 25.5\%; 2017 - 47.8\%; 2018 $51.9 \% ; 2019-56.9 \%$

Thinking and Reasoning: 2016 - 21.6\%; 2017 - 43.3\%; 2018 $50.2 \% ; 2019-53.7 \%$

These results show some improvement: the teacher had more knowledge about the pedagogy of teaching comprehension skills in both first and second language. These literacy issues motivated the principal researcher to explore how she could develop higher-order comprehension skills in her Grade 3 class teaching HL and English First Additional Language (EFAL), where the language of learning and teaching (LoLT) is different from the mother tongue language of the learners. The South African Curriculum and Assessment Policy Statement (CAPS) document (DBE 2011a) states that in the first few years of schooling the focus is on developing learners' ability to understand and communicate interpersonally. In Grade 2 and Grade 3 learners begin to expand their literacy skills on this oral foundation. Hence the research question is: 'What comprehension skills did the learners develop during the 10-week intervention programme?'

Pretorius and Spaull (2016) stated that South African learners perform extremely poorly regardless of what language the reading tasks are assessing. This is confirmed by Statistics South Africa (2019:95) in stating that the quality of learning in the South African school system is a national challenge. A weak foundation in the early grades of learning literacy creates difficulties for learners in the later grades. The target for the National Development Plan (National Planning Commission 2011) is 90\% for all Grade 3 learners and 50\% or more in the national literacy assessments. Statistics South Africa states that it is important to plan to achieve this target by ensuring that all learners in South Africa acquire the knowledge and skills needed to eliminate poverty and reduce inequality in this developing country. The World Bank Group (WBG 2018) posits that developing countries and lowincome countries are facing low learning levels. This is true in South Africa, as many learners from poor households are far more likely to struggle to acquire basic literacy skills and continue functioning at a low learning level.

As has been described, there is a plethora of research being conducted on the continued poor literacy rates of many of
South African Foundation Phase learners (Pretorius \& Spaull 2016; Statistics South Africa 2019; Taylor 2014; Van der Berg et al. 2016). These low literacy rates emanating from a poor reading culture, particularly among township second language learners, constrain their ability to comprehend texts and develop higher-order thinking skills. This study is therefore of theoretical and educational importance as it investigated effective comprehension strategies for developing higher-order thinking skills of Grade 3 second language learners.

\section{Literature review}

Comprehension is the product of a learner's decoding and listening skills (Piper, Schroeder \& Trudell 2015; Piper, Zuilkowski \& Mugenda 2014). It requires learners to demonstrate understanding of concepts, to read by answering questions and interpreting the content. Piper et al. (2014) explain that readers build ideas by combining the information in texts with what they already know. A learner reads the text and infuses his or her understanding with prior knowledge about the subject. The South African CAPS document (DBE 2011a) highlights that the national curriculum aims to produce learners who are able to:

$[I]$ dentify and solve problems, make decisions using critical and creative thinking, work effectively as individuals and as members in a team, collect, analyse, organize and critically evaluate information and to see the world as a set of related systems by recognizing that problem solving contexts do not exist in isolation. (p. 5)

Paradoxically, this is not happening in our South African schools: many researchers (Mudzielwana et al. 2012; Pretorius \& Spaull 2016; Verbeek 2010) contend that too much time is spent on decoding skills and not enough time on developing meaning-making and higher-order thinking skills, especially with learners learning in their second or third language. Yen and Halili (2015) believe that developing learners' higherorder thinking skills creates critical thinking in learners who can respond to real-world difficulties. They state that critical thinking skills do not function naturally: these skills need to be explicitly developed so that learners can achieve their highest thinking abilities.

The Constitution of the Republic of South Africa guarantees that South African children have a right to receive education in their HL or language of their choice. Since South Africa has 11 official languages, most learners do their first 3 years in their first or HL as the LoLT (Pretorius \& Spaull 2016). Other than English and Afrikaans, this means that there are nine African languages that can be used as LoLT in the Foundation Phase (FP). The DBE policy on HL and EFAL posits that HL should be the language of teaching in Grades 1-3. One of the language skills introduced in Grade 1 is listening and speaking in English. Other language skills such as reading, viewing and writing are introduced from Grade 2 to Grade 3. In Grade 4 learners transition from using the HL as LoLT to the use of English. In this study, the principal researcher introduced the Grade 3 learners to the use of English to 
complete comprehension tasks as she believed it would assist them to transition more smoothly to Grade 4 (Pretorius \& Klapwijk 2016), where they have nine subjects as opposed to the four in Grade 3. Hence, reference is made to Mullis, Martin and Sainsbury's (2016) study, which showed that readers create meaning in different ways. The PIRLS literacy assessments test four comprehensively constructed skills of comprehension which are:

- focus on and retrieve explicitly stated information

- make straightforward inferences

- interpret and integrate ideas and information

- evaluate and examine content and textual elements.

These four comprehension skills are the metacognitive skills and strategies that allow readers to examine their understanding and adjust their approach to answering comprehension questions (Mullis et al. 2016). These were used as the foundation for developing the comprehension questions in this research. Sari and Sari (2019) state that for learners to gain good understanding in reading a text, teachers have to provide them with some interesting strategies to improve their reading comprehension. The authors argue that different and interesting strategies can be used to make the learning atmosphere enjoyable and increase their motivation. Sonmez and Sulak (2018) agree that reading comprehension strategies are the cognitive tools that can improve the academic performance of learners for whom comprehension is a challenge. The following is a brief description of nine comprehension strategies that were used in this research project to develop the comprehension skills of five Grade 3 learners.

\section{Anticipation guides}

Adams, Pegg and Case (2015) state that an anticipation guide is a reading comprehension strategy designed to scaffold learners as they grapple with texts. Sari and Sari (2019) extend this definition by stating that anticipation guides use a series of statements to involve learners in making predictions. In order to do this, learners may depend on prior knowledge. The average number of statements may range from 6 to 12. For each statement, learners indicate whether they 'agree' or 'disagree' with the statement. Most of the statements must be true or false but a few must be written to be debated, discussed or argued.

\section{Vocabulary - Magic square}

Vacca and Vacca (2005:287) explain the magic square strategy as an activity sheet that has two columns: one for content area terms and one for definitions. Learners are asked to match terms with definitions. In doing so, they must take into account the letters signalling the terms and the numbers denoting the definitions. The learners then put the number of a definition in the proper space (denoted by the letter of the term) in the 'magic square answer box'. If their matchups are correct, they will form a magic square. The numerical total will be the same for each row across and each column down the answer box. This total forms the puzzle's 'magic number'.

\section{Vocabulary - Matching}

Nam (2010) states that effective strategies to teach vocabulary can assist learners' proficiency in the four language skills: listening, speaking, reading and writing. She states that vocabulary matching activities can be designed by teachers so that learners develop new vocabulary and understand different features of vocabulary.

\section{Feature matrix}

To provide learners with the correct content and facts about a theme, the feature matrix compares different features of classification by finding their similarities and differences in a text. In this strategy, the teacher begins by making different informational texts available to learners (Calo 2011). These informational texts help learners to become familiar with the concepts of the content (Maloch \& Horsey 2013).

\section{Think aloud}

The 'think-aloud' comprehension strategy is modelled to learners to allow them to share the development of their thinking strategies and to make their thoughts noticeable (Sonmez \& Sulak 2018). Learners are able to focus their thinking better when they participate in the 'think-aloud' strategy while it is being role-modelled by the teacher. The main purpose of this strategy is to support learners to obtain the ability to independently think aloud.

\section{My turn, your turn}

Nomlomo (2010:51) states that in a classroom interaction 'my turn, your turn' is initiated by the teacher through asking questions or giving instructions. Learners receive turns by responding to a teacher's questions or instructions. She states that the kind of responses given by learners determines the kind and quality of questions posed by the teacher. This is considered as important in the 'my turn, your turn' strategy. Van Eerde, Hajer and Prenger (2008) agree that to facilitate effective communication in the classroom, it is vital that learners are provided with challenging, comprehensible and scaffolding input with meaningful feedback.

\section{Reader's theatre}

Qannubi, Gabarre and Mirza (2018) state that 'reader's theatre' can be used as a fun and exciting strategy in a classroom. 'Reader's theatre' is regarded as a play or a performance of a written text which delivers meaning to the audience if repeated and supported in reading. By including 'reader's theatre' in learning literacy skills, this strategy arouses an interest in reading for meaning and improves learners' comprehension, reading fluency and self-confidence.

\section{Cloze}

Ereke and Okonkwo (2016) state that the 'cloze' strategy describes how individuals learn to complete a pattern. They are a type of fill-in-the-blank space with every six or seven 
words in the passage. This strategy can be used for different purposes such as testing language proficiency, reading comprehension, measuring the complexity of a comprehension text, reading for meaning, proficiency, and as a pedagogical tool.

\section{Higher-order thinking comprehension}

Shukla and Dungsungnoen (2016) state that this is an important strategy. Learners discover how to analyse, interpret, reason, synthesise, evaluate and create their own meaning and understanding. This teaching strategy increases metacognition: this skill is needed in problem-solving, as well as comparing, evaluating, justifying and making inferences.

\section{Conceptual framework}

This study intersects three pedagogic priorities: Vygotsky's (1978) theory of social constructivism, Cambourne's (2004) instructional theory and Bloom's taxonomy (Forehand 2018) theory of cognitive domain. Interlinking these three theories provides background information on key relations between knowledge that is socially constructed, and higher-order thinking skills resulting in comprehension achievement.

Vygotsky was himself educated by a private tutor who taught using critical inquiry and philosophical discussions (Verenikina 2010). From these lived experiences, Vygotsky developed his theory on the role of social interaction, where both teachers and learners are active agents in the learning and development process.

What is central for effective transference of knowledge is the quality of the teacher's interaction. While the researcher was posing comprehension problems to her group of five learners, allowing them to collaborate among themselves and learn from the stronger learners, Vygotsky's zone of proximal development (ZPD), was constantly being foregrounded. The researcher assisted her learners marginally beyond their current capability but was always mindful of extending their present higher-order thinking skills (Cole \& Cole 2001).

It was important for her to be 'ahead of her learners', meaning she needed to know their 'actual and potential development' (Verenikina 2010:18). She was constantly shifting her learners to higher levels of understanding, by engaging them in cooperative dialogues, with herself as the more knowledgeable other (MKO), and encouraging them to take the language being used in the class and make it part of their own, and then to use this speech in organising their own performances. These internal developmental processes happened with the researcher expecting the learners to participate in dialogue in all the strategies she introduced them to throughout the 10week intervention programme (IP).

Similar to Vygotsky, Cambourne believed that knowledge and meaning are socially constructed through the processes of negotiation, evaluation and transformation. He believed that learners must experience 'intellectual unrest' if they are to engage with discussions and draw from their background experiences (Cambourne 2004:36). Transformation occurs when teachers create classroom environments where there is a deep exchange of knowledge and skills with multiple demonstrations. These discussions allow learners to explore, reflect on their learning and clarify meaning; all these depend on the level of application. Learners need to apply the skills taught by the teacher. Finally, they evaluate their own performances.

Bloom's taxonomy was used in this study as a pedagogical tool to improve the cognitive skills of the five selected learners. The researcher attempted to move her learners from the lower-order levels of Bloom's taxonomy (Forehand 2018) to higher-order thinking skills. She built upon, and extended, their knowledge. She guided them to construct new knowledge from the texts and encouraged her learners to transfer this new knowledge to their own communities by applying and implementing what was learnt in the texts. She role-modelled analytical skills by breaking texts into smaller parts and created opportunities for the learners to evaluate texts by offering opinions about the texts.

\section{Research design and methods Study design}

A qualitative approach, using a case study design, within an interpretivist paradigm was purposefully devised for this project and deployed consistently for the gathering and interpretation of both visual and textual data. The numerical scores from the pre-tests and post-tests were converted into quantitative data to provide visual representations using Microsoft Excel. These numerical graphs were then analysed to provide qualitative meaning to the values (Antieno 2009). As the participants expressed their views during the IP, the researcher was able to interpret what she observed, and was able to understand their experiences and interactions.

\section{Setting}

The school is situated in Nyanga, a low socio-economic area of Cape Town. This community has 10 primary schools and two high schools. The majority of learners in this school are from the neighbourhood, where there is drug abuse, high unemployment rates, teenage pregnancy, and teenage parents with low literacy levels. The researcher taught a Grade 3 class in this public school which will be referred to as School X.

School X is a quintile 2, no-fee school, (Gower 2008:15) where learners receive free books and food, three times a day. Jomaa, McDonnell and Probart state (2010) that the purpose of a school feeding programme is to relieve short-term hunger, improve nutrition and to facilitate the cognitive development of learners.

There are three classes per grade from Grades $\mathrm{R}$ to 3 with a teacher learner ratio of 1:35. The LoLT from Grades R to 3 is IsiXhosa. From Grades 4 to 7 the LoLT is English. In 2018, at the time of this research project, there were 718 registered learners. 


\section{Participants}

The participants for this study were purposively selected (Fraenkel, Wallen \& Hyun 2012). Five Grade 3 learners were selected to be part of this study as they were facing severe comprehension challenges; they were the worst performing literacy learners in the class. A small sample of only five learners was preferred since the researcher intended to interact extensively with them (Creswell 2012). Two Grade 3 teachers were interviewed, as they were able to provide more information about the comprehension challenges they faced with their Grade 3 learners. The parents and guardians of the five learners were interviewed in an attempt to understand the learners' literacy challenges outside the classroom.

\section{Intervention programme}

An IP was developed where five Grade 3 'learners at risk' were identified. This 10-week IP was conducted from 10 April to 14 June 2018, 3 days a week, after school hours from 14:00 to 14:30. The first and last weeks were used to conduct pre-tests and post-tests. The actual teaching, which focused on building higher-order comprehension skills, was undertaken in between. In an attempt to reduce the learners' risk (Thompson et al. 2004), the actual teaching was conducted during the middle 8 weeks. For this process to be beneficial to the learners, the programme was structured around the correct level and pace of the learners, supporting Vygotksy's ZPD concept.

Pre-tests and post-tests were developed as a measure of learning outcomes and skills before and after the teaching sessions took place, as well as evaluating the teaching methods (Ivanitskaya et al. 2008). These informal tests included a variety of Grade 1 to Grade 4 passages. Providing a variety of passages meant that the learners would be able to read and answer questions from a range of texts, with increased levels of complexity. This diagnostic information would provide the researcher with information about each learner's strengths and challenges. Each text included four question types similar to those used in the PIRLS assessments: (1) focus on retrieving explicitly stated questions, (2) making straightforward inferences, (3) interpreting and integrating ideas and information and (4) evaluating and examining content, language and textual elements. The justification for using these four comprehension question types is that they are similar to those used by the WCED systemic tests. The texts were developed by a group of Honours students over a period of 3 years and were trialled with their own class learners. The necessary changes were made to the texts and questions. The same post-test texts and questions were used.

Before the IP began, the researcher and her supervisor planned a draft schedule to guide them over the 10 weeks. This plan includes dates, times and content of what strategies to teach. They were cognisant of including Cambourne's (2004) eight conditions of learning: immersing learners in active learning environments, demonstrating how to ask questions and listen to each other, engaging in discussions sharing ideas and skills, setting high expectations of learners, allowing learners to take responsibility for their own decision-making and engagement, providing learners with time and opportunities to explore texts, encouraging learners to take risks and make predictions and allowing the more knowledgeable peers to help learners adjust, modify and extend their learning.

The reason for reinforcing strategies was to allow learners to become familiar with them, moving them from being dependent to independent learners (Vygotsky 1978). These strategies provided different cognitive levels as Forehand (2018) and the CAPS (DBE 2011a) document describe.

\section{Data collection}

Five parents or guardians were selected to be interviewed. The researcher intended to find out more about the learners' comprehension challenges outside the classroom. She included two Grade 3 teachers in this study since they were teaching comprehension skills in their classes and were able to provide information about the comprehension challenges they face with their learners from a teacher's perspective.

Twelve semi-structured interviews allowed the researcher to probe and explore interviewees' attitudes, opinions and feelings (Lambert 2012). Some of the interviews were conducted during the week, inside the school premises. Others took place at participants' homes during weekends and lasted for 45 to $60 \mathrm{~min}$. They were conducted in isiXhosa, a language with which the participants were comfortable.

As a participant observer, the researcher observed the five Grade 3 learners during the 10-week IP with the specific aim of (1) immersing herself in the activities with which the five learners were occupied (Cohen, Manion \& Morrison 2017) and (2) recording the rich data she was observing. She believed that by doing this, it gave her a true and accurate view of what was actually happening, rather than relying on inferences. It was sometimes difficult for her to record all the information while participating in an activity. She made time to write up her reflections immediately after each lesson.

In this study, the researcher used the learners' five exercise books, in which they reflected on their learning experiences by using authentic language and words. These books helped the researcher find important information that enabled her to assess and analyse the fundamental phenomena in her study (Creswell 2012).

\section{Data analysis}

Qualitative data were inductively analysed using content analysis. All the data were translated from isiXhosa to English, transcribed by the researcher (Creswell 2012) and checked for accuracy by the interviewees themselves, all of whom were native isiXhosa-speaking people. She used this method of summarising many words into a few categories (Cohen et al. 2017). These smaller units were based upon 
theories, experiences and previous knowledge (Fraenkel et al. 2012). While inductively analysing all the data, she began to recognise patterns and similarities which she marked in different colours (Creswell 2012). Themes were developed which were linked to the literature review and relevant theories (Creswell 2012). The numerical scores from the pre-tests and post-tests were analysed qualitatively.

The principal researcher, who was also the class teacher, did not permit personal issues, such as bias or power, to affect her interpretation. She was thoughtful and respectful towards her participants. She used language that avoided 'demeaning attitudes, biased assumptions, and awkward constructions that suggested bias because of gender, sexual orientation, racial or ethnic group, disability or age' (Creswell 2012:277). She avoided bias by selecting two teachers as part of the sample who were different in terms of age and work experience, and learners who were different in gender. To ensure the reliability of the test scripts, the scripts were marked twice to double-check the errors.

\section{Ethical considerations}

The researchers received ethical clearance (EFEC 4-2/2018) from the university where the authors were studying, from the WCED and approval from the principal, two teachers and learners' parents or guardians. The researcher made sure that all the voluntary participants understood the purpose of the study and were informed that they could withdraw at any time. All participants and the school were allocated pseudonyms to protect their identities. The participants are referred to using numbers, such as Learner 1 (L1), Teacher 1 (T1) and Parent 1 (P1).

\section{Results}

To answer the research question, 'What comprehension skills did the learners learn during the 10-week IP?' the researcher presents the pre-test and post-test results of the five Grade 3 learners (see Figure 1 and Figure 2) and provides discussions on each learner's performance. The discussion will be based on the learners' reactions to the following four levels of questions:

Level 1: Focus on and retrieve explicitly stated information.

Level 2: Make straightforward inferences.

Level 3: Interpret and integrate ideas and information.

Level 4: Evaluate and examine content, language and textual elements.

By the end of the 10-week IP, the five Grade 3 learners made significant improvements in their understandings of the four PIRLS comprehension skills. The researcher now discusses each of the five learners' pre-test and post-test responses to the questions from various texts. Since these tests were written exercises, the authentic verbatim responses of the learners have been provided to show the progress of learners.

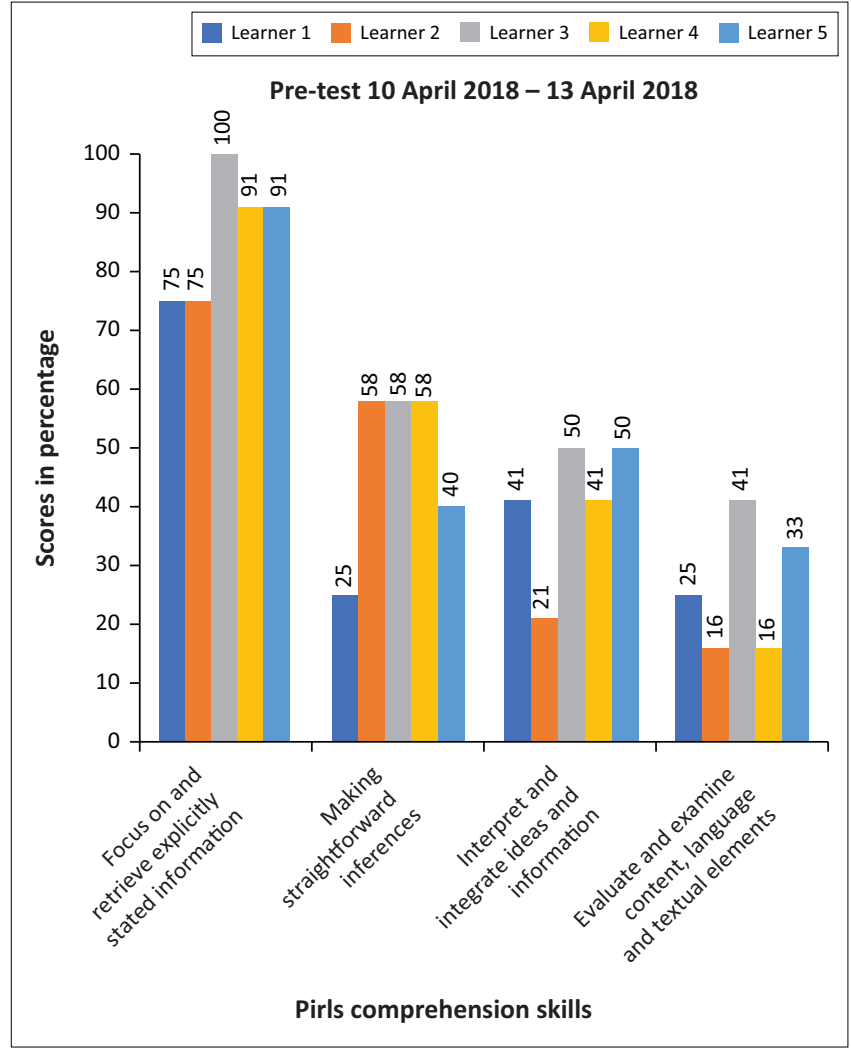

FIGURE 1: The pre-test results of the five Grade 3 learners.

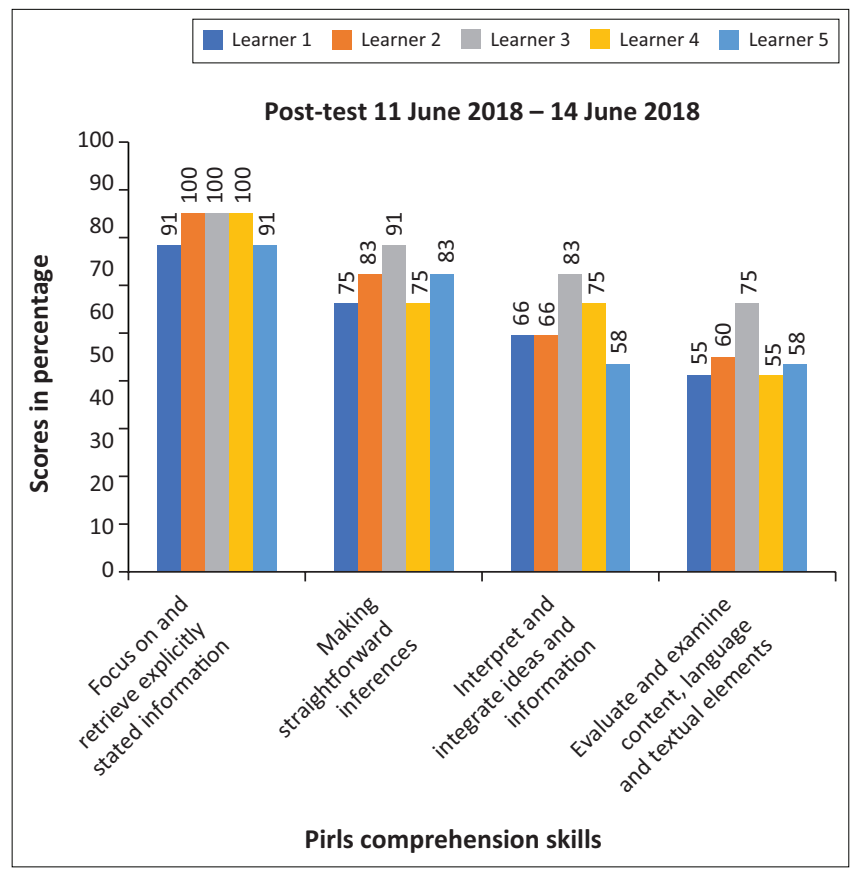

FIGURE 2: The post-test results of the five Grade 3 learners.

\section{Learner 1 (L1)}

For L1, there was not much of an improvement in the skill 'focus on and retrieve explicitly stated information'. At the beginning of the IP, T2 narrated:

'To be honest our learners do not want to read because this type of question requires them to look for answers in the text but they still get wrong answers'. (Teacher 2) 
TABLE 1: L1's written pre-test and post-test responses.

\begin{tabular}{|c|c|c|}
\hline \multirow{2}{*}{$\begin{array}{l}\text { Grade } 2 \text { passage } \\
\text { Comprehension questions }\end{array}$} & \multicolumn{2}{|c|}{ Title of the passage: Playing in the leaves } \\
\hline & Pre-test answers & Post-test answers \\
\hline \multicolumn{3}{|l|}{ What season is it? } \\
\hline Level 1 & Season is sun & The season is Autumn \\
\hline \multicolumn{3}{|c|}{ What colours do you think the leaves are? } \\
\hline Level 2 & The leaves are autumn & The leaves are brown \\
\hline \multicolumn{3}{|c|}{ What does your garden look like in Autumn? } \\
\hline Level 3 & Is nase & $\begin{array}{l}\text { The garden is orange and } \\
\text { brown }\end{array}$ \\
\hline \multicolumn{3}{|c|}{ Do you agree that Autumn is the best season and why? } \\
\hline Level 4 & Yes because in nace & Yes, because is my best season \\
\hline
\end{tabular}

TABLE 2: L2's written pre-test and post-test responses.

\begin{tabular}{|c|c|c|}
\hline \multirow{2}{*}{$\begin{array}{l}\text { Grade } 3 \text { passage } \\
\text { Comprehension questions }\end{array}$} & \multicolumn{2}{|c|}{ Title of the passage: The donkey and the little dog } \\
\hline & Pre-test answer & Post-test answer \\
\hline \multicolumn{3}{|c|}{ What kind of pet did the man have? } \\
\hline Level 1 & $\begin{array}{l}\text { The kind of pet did the } \\
\text { man have is dog }\end{array}$ & $\begin{array}{l}\text { The kind of the pet } \\
\text { man is dog }\end{array}$ \\
\hline \multicolumn{3}{|c|}{ What is the difference between a pet and a wild animal? } \\
\hline Level 2 & $\begin{array}{l}\text { The difference between a pet } \\
\text { and wild animal they donkey } \\
\text { is big are dog was small }\end{array}$ & $\begin{array}{l}\text { The pet is not eat } \\
\text { the people and wild } \\
\text { animals is dangerous }\end{array}$ \\
\hline \multicolumn{3}{|c|}{ If you were the donkey, how would you feel? Why would you feel this way? } \\
\hline Level 3 & $\begin{array}{l}\text { I'm feel sad and angry because } \\
\text { I'm big me I not are small and } \\
\text { I'm not are dog }\end{array}$ & $\begin{array}{l}\text { I feel sad because } \\
\text { I'm not pet of man }\end{array}$ \\
\hline \multicolumn{3}{|c|}{ Would you agree that the man treated the donkey unfairly and why? } \\
\hline Level 4 & $\begin{array}{l}\text { Yes because a men are not } \\
\text { are trat are dog }\end{array}$ & $\begin{array}{l}\text { Yes, because is not } \\
\text { are pet }\end{array}$ \\
\hline
\end{tabular}

Despite this comment from T2, L1 began the IP with a strong base in this particular skill, receiving $75 \%$, and showing a slight improvement of $16 \%$ in the post-test results. The greatest improvement in the post-test was for the comprehension skill of 'making straightforward inferences with understanding' which improved by $50 \%$. There was a $25 \%$ improvement in the 'interpreting and integrating ideas and information' comprehension skill. By the end of the IP, L1 had moved from lower-order levels of Bloom's taxonomy (Forehand 2018) to being able to interact more confidently with higher-order thinking skills.

This modest improvement could have been the result of L1's change in identity in Week 8 when he narrated in his reflection that: 'I am now able to explain my choices'. His confidence in speaking English improved so he was able to think and share his critical thoughts. By socially engaging with explicitly stated higher-order questions, L1 emerged as an independent learner (Verenikina 2010) and this environment contributed to making the group activities less stressful for him. This is confirmed by the way L1 responded in the post-tests as can be seen in Table 1.

\section{Learner 2 (L2)}

$\mathrm{T} 1$ mentioned in her interview:

'Today's education does not allow our learners to be critical thinkers. At Grade 3 level when analysing the text our learners struggle to find the author's message, summarise the text and to blend what they read in the story with their real life'. (Teacher 1)

L2's post-test results showed that she improved in all four comprehension skills, indicating that, despite the comment
TABLE 3: L3's written pre-test and post-test responses.

\begin{tabular}{|c|c|c|}
\hline \multirow{2}{*}{$\begin{array}{l}\text { Grade } 3 \text { passage } \\
\text { Comprehension questions }\end{array}$} & \multicolumn{2}{|c|}{ Title of the passage: A strange visitor to the school } \\
\hline & Pre-test answer & Post-test answer \\
\hline \multicolumn{3}{|c|}{ Who said her lunch was stolen? } \\
\hline Level 1 & $\begin{array}{l}\text { Is Bongi said my lunch was } \\
\text { stolen }\end{array}$ & Its Bongi \\
\hline \multicolumn{3}{|c|}{ Why do you think a goat is a strange visitor to the school? } \\
\hline Level 2 & Because is all was a goat & $\begin{array}{l}\text { Because goats do not } \\
\text { stay in school }\end{array}$ \\
\hline \multicolumn{3}{|c|}{ Have you ever felt unsafe at school? How did it make you feel? } \\
\hline Level 3 & $\begin{array}{l}\text { No because are was } \\
\text { tsaying in my home }\end{array}$ & Yes, sad \\
\hline \multicolumn{3}{|c|}{$\begin{array}{l}\text { Do you agree that it was good of everyone to help fix the school fence? Why do } \\
\text { you think so? }\end{array}$} \\
\hline Level 4 & Yes day will be goat inside & $\begin{array}{l}\text { Yes, because the goat } \\
\text { will not get in the school }\end{array}$ \\
\hline
\end{tabular}

made by T1, she was able to be a 'critical thinker'. The most noticeable improvements were her ability to answer the 'interpret and integrate ideas and information' where she integrated texts with her real-life situations.

Contrary to L2 experiencing a language barrier, L2 shared during the interview, that she 'enjoyed practising to role-play every story she read she even asked her mother to speak in English with her at home'. This enjoyment indicates that she was committed to improving her comprehension skills understanding. The enjoyment of speaking to L2's mother is confirmed by Vygotsky (cited in Verenikina 2010:17) who emphasised that 'children and adults are both active agents in the process of the child's development'. Through this coconstructing process, she gained self-confidence when participating in the class activities. This improvement is shown in Table 2 by the way she answered the post-test questions compared with the pre-test answers. Her post-test answers indicated how her sentence construction improved and how she thought more logically before she answered the questions. Learning, at the higher-order thinking level, was occurring in her ZPD (Forehand 2018; Verenikina 2010).

\section{Learner 3 (L3)}

Although L3 began this IP with strong pre-test results, the post-test results revealed noticeable improvements in his understanding of these higher-order comprehension skills.

L3's parent stated that: 'He is able to read words but when I ask the meaning of some words he struggles with the meanings'. Although, Pretorius and Klapwijk (2016:2) state that 'low parental literacy is only one factor for the poor levels of reading comprehension in South Africa', L3's parent actively participated in developing his literacy skills by asking the meanings of some of the words.

His pre-test and post-test, however, demonstrated that he received the highest marks in all the comprehension skills of the five learners; he had achieved Bloom's higher-order thinking skills (Forehand 2018). In his reflections, he wrote: 'my group mates ask me to explain to them so that's making me feel excited about these lessons'. While he was assisting his classmates, he was learning and benefiting from these experiences. Table 3 shows how he was able to comprehend 
TABLE 4: L4's written pre-test and post-test responses.

\begin{tabular}{|c|c|c|}
\hline \multirow{2}{*}{$\begin{array}{l}\text { Grade } 1 \text { passage } \\
\text { Comprehension questions }\end{array}$} & \multicolumn{2}{|c|}{ Title of the passage: Rabbit and Mole } \\
\hline & Pre-test answer & Post-test answer \\
\hline \multicolumn{3}{|l|}{ What did Rabbit use to dig? } \\
\hline Level 1 & $\begin{array}{l}\text { Rabbit dig leg and long } \\
\text { claws }\end{array}$ & $\begin{array}{l}\text { He used his strong front } \\
\text { feet }\end{array}$ \\
\hline \multicolumn{3}{|l|}{ What does snooze mean? } \\
\hline Level 2 & drink & It means sleep \\
\hline \multicolumn{3}{|c|}{ Has anyone tried to bully you? How did it make you feel? } \\
\hline Level 3 & No, it makes me happy & Yes, it makes me feel sad \\
\hline \multicolumn{3}{|c|}{ Was this a happy or a sad story - Can you explain? } \\
\hline Level 4 & $\begin{array}{l}\text { It was a happy story. } \\
\text { Because rabbit was happy } \\
\text { when he was digging }\end{array}$ & $\begin{array}{l}\text { It was a sad story because } \\
\text { rabbit is bullying mole }\end{array}$ \\
\hline
\end{tabular}

all four levels of questions, and his writing skills were more understandable. As L3 was engaging in cooperative dialogues with his peers, they were able to take L3's language and make it part of their own private speech, and use this speech to organise their private independent performances until they become internalised (Verenikina 2010). These developmental processes can only become sustained learning when people are interacting with more experienced people and, in this case, L3 willingly took on that role.

\section{Learner 4 (L4)}

Before the IP, T2 was asked: 'How do your learners explain or summarise texts?'. She stated:

'The children we teach today, they struggle to explain in their own words, what they read or what is being read to them. They are so lazy to think out of the box and to express their views.' (Teacher 2)

L4's post-test results indicate, however, that she showed a consistent improvement in her higher-order thinking skills, and she grew in confidence being able to share her opinions. By Week 7 she began to evaluate her own responses and became more confident in justifying her answers. This indicates that she was achieving the highest levels of cognition as can be seen in Table 4 comparing L4's written pre-test and post-test contributions. Her written answers were more to the point, correct and she provided reason for her answers. This example demonstrates that during the IP L4's language and both her higher-order and lowerorder comprehension thinking skills improved. Cambourne (2004:36) explains that 'transformation occurs when learners transform their knowledge that others have modelled into knowledge that is uniquely their own'. At the beginning of the IP, L4 was in a state of 'intellectual unrest' (Cambourne 2004:36), unable to understand the higher-order questions. The 10-week IP provided her with 'continuous opportunities for intellectual unrest to be resolved', with her eventually developing Bloom's taxonomy's highest levels of critical thinking (Anderson \& Krathwohl 2001).

\section{Learner 5 (L5)}

Teacher 1 responded to the interview question 'Do you teach inference skills?'. 'To be honest, I myself do not know what an inference is'. This response relates to what many researchers,
TABLE 5: L5's written pre-test and post-test responses.

\begin{tabular}{|c|c|c|}
\hline \multirow{2}{*}{$\begin{array}{l}\text { Grade } 3 \text { passage } \\
\text { Comprehension skills }\end{array}$} & \multicolumn{2}{|c|}{ Title of the passage: The new bike } \\
\hline & Pre-test answer & Post-test answer \\
\hline \multicolumn{3}{|c|}{ Question: How did Thabo's new bike look? } \\
\hline Level 1 & It was bright and shiny red & Thabo's new bike was red \\
\hline \multicolumn{3}{|c|}{ Question: What is meant by the word 'litter'? } \\
\hline Level 2 & $\begin{array}{l}\text { The word litter means } \\
\text { bright }\end{array}$ & $\begin{array}{l}\text { It means things that you } \\
\text { don't put in the bin }\end{array}$ \\
\hline \multicolumn{3}{|c|}{$\begin{array}{l}\text { Question: Have you ever borrowed something from someone and broken it? } \\
\text { How did you feel? }\end{array}$} \\
\hline Level 3 & No, not happy & $\begin{array}{l}\text { Yes, I felt sad because I pay } \\
\text { it back }\end{array}$ \\
\hline \multicolumn{3}{|c|}{ Question: What can you learn from the story? } \\
\hline Level 4 & $\begin{array}{l}\text { That you can borrow things } \\
\text { but don't broke them }\end{array}$ & $\begin{array}{l}\text { That you can borrow things } \\
\text { but don't broke them }\end{array}$ \\
\hline
\end{tabular}

such as Mudzielwana et al. (2013), Pretorius and Currin (2010), Pilanieta and Medina (2009), and Pretorius and Klapwijk (2016), have found in their studies. These researchers found that teachers, from primary to high school, do not know how to model the teaching of comprehension skills.

It was, therefore, pleasing to note that L5 showed a noticeable improvement in the second comprehension skill where he was 'making straightforward inferences' with understanding. In Week 5 he reflected that: 'I was able to give suggestions and share ideas to the group'. The confidence that developed from 'giving suggestions' and 'sharing ideas with the group' helped him to develop Bloom's higher-order thinking skills (Anderson \& Krathwohl 2001) which have become evident in his written responses from his pre-test and post-test questions in Table 5. His post-test answers suggest that by the end of the IP his language usage improved and he was confident to justify his answers correctly.

\section{Discussion}

The aim of this article was to explore 'what comprehension skills learners develop during a 10 -week $\mathrm{IP}^{\prime}$. The post-tests show that all five 'at risk' learners made significant improvements in their understandings of the four comprehension skills with some learners achieving higher levels of criticality than others. This concurs with the view of Yen and Halili (2015) who state that when learners are exposed to an intensive language acquisition programme, it helps them develop their higher-order thinking skills. This improvement enables them to become critical thinkers who can solve problems on their own. Anderson and Krathwohl (2001) argue that in every level of education, there is a need to try to get learners to reach the highest levels in Bloom's taxonomy.

Despite low parental literacy rates and teachers either not believing in, or not knowing how to teach, higher-order critical thinking skills in South Africa (Pretorius \& Klapwijk 2016), these five learners showed steady progress over the 10-week IP, where they developed through Bloom's taxonomy's lower-order cognitive skills to the higher-order cognitive skills and were able to evaluate texts. Lee (2015) postulates that the use of questions helps learners make cognitive progress, to where they would be able to create 
new things. This resonates with the findings of this study of the five learners, who initially were only able to answer lower-order comprehension questions, and progressed to freely and willingly participate in higher-order thinking skills discussions. They finally created new ideas and information using what was previously learned from former texts and linking the content to their own experiences. It is important to note that the learners' ability to progress is dependent not only on their cognitive abilities, but also on the social interactions that teachers promote (Vygotsky 1978). Like Vygotsky, Cambourne (2004) reiterates that knowledge and meaning are socially constructed through a series of negotiations, evaluations and transformations.

The CAPS document requires Grade 3 learners to develop the essential language skills of reading and viewing, listening and speaking in EFAL. English is the second language of these learners yet their oral skills developed week by week as the learners learnt to listen to the texts being read and responded by speaking in English in full sentences. This is an element of social interaction and language development that is pivotal in the learning theories of social constructivists (Cambourne 2004; Vygotsky 1978). By working in a small group of five, the learners learnt social skills and grew confident enough to participate in group discussions to learn from each other.

\section{Conclusion}

The results of the pre-tests indicate that the five learners initially lacked an understanding of the four comprehension skills questions. The data presented discusses the challenges that these five learners faced within the four comprehension skills. Bearing in mind the variables, which were similar to the pre-test conditions, the post-test results showed significant improvements in all four comprehension questions. It was unexpectedly pleasing to note the range of such upward movements in the results of each learner.

By amalgamating elements of Vygotsky's (1978) theory of social constructivism, Cambourne's (2004) instructional theory and Bloom's taxonomy (Forehand 2018) a sound and workable platform was created that suited the particular statistical parameters and theoretical requirements of this project. All the activities that were used with the learners encouraged social integration, sharing opinions and working constructively together. By doing this, the students challenged each other's cognitive development, so that over the 10-week period, the learners grew in confidence, and were able to transform their own zones of abilities and independent thinking to higher levels of Bloom's application.

This study was limited to five Grade 3 'at risk' learners who participated in a controlled 10-week IP focusing on developing higher-order comprehension skills. This study does not claim to be generalisable. Although the sample was small, it is possible that its findings may be generalised by analogy to similar contexts. The researcher suggests three recommendations.
First, it is recommended that this study, which contributes towards improving the higher-order critical comprehension skills of our FP learners, may be used by higher education institution lecturers when training FP teachers.

Second, it is recommended that teachers begin reflecting on their own teaching strategies, and develop similar IPs, incorporating these nine strategies, to improve the comprehension skills of their learners.

Finally, this study may assist WCED's district-based support teams and higher education institutions by contributing to their professional development training courses focusing on the explicit teaching of comprehension skills.

\section{Acknowledgements}

Tha authors would like to acknowledge Dr Curr for the language editing of this article.

\section{Competing interests}

The authors have declared that no competing interest exists.

\section{Authors' contributions}

J.C. acted as main supervisor for V.F.'s master's degree. L.M. and H.P. were co-supervisors and critical readers while V.F. wrote most of the article.

\section{Funding information}

This research received no specific grant from any funding agency in the public, commercial, or not-for-profit sectors.

\section{Data availability}

The authors confirm that the data supporting the findings of this study are available within this article.

\section{Disclaimer}

The views and opinions expressed in this article are those of the authors and do not necessarily reflect the official policy or position of any affiliated agency of the authors.

\section{References}

Adams, A.E., Pegg, J. \& Case, M., 2015, 'Anticipation guides: Reading for understanding', Mathematics Teacher 108(7), 499-504. https://doi.org/10.5951/mathteacher 108.7.0498

Anderson, L.W. \& Krathwohl, D.R. (eds.), 2001, A taxonomy for learning, teaching, and assessing: A revision of Bloom's Taxonomy of educational objectives, Allyn \& Bacon, Boston, MA.

Antieno, O.P., 2009, 'An analysis of the strengths and limitations of qualitative and quantitative research paradigm', Problems of the Education in the 21st Century 13 , 13-18, viewed 25 October 2019, from https://www.scientiasocialis.It/pec/files/ pdf/AtienoVol.13pdf.

Calo, K.M., 2011, 'Comprehending, composing, and celebrating graphic poetry', The Reading Teacher 64(5), 351-357. https://doi.org/10.1598/RT.64.5.6

Cambourne, B., 2004, 'Holistic, integrated approaches to reading and language arts instruction: The constructivist framework of an instructional theory', in A.E. Farstrup \& S.J. Samuels (eds.), What research has to say about reading instruction, 3rd edn., pp. 5-47, The International Reading Association, Newark, DE. 
Cohen, L., Manion, L. \& Morrison, K., 2017, Research methods in education, 8th edn., Routledge, London.

Cole, M. \& Cole, S., 2001, The development of children, 4th edn., Scientific American Books, New York, NY.

Creswell, J.W., 2012, Educational research: Planning, conducting, evaluating quantitative and qualitative research, 4th edn., Pearson, Lincoln, NE.

Ereke, J.S. \& Okonkwo, F.A., 2016, 'Cloze procedures and Nigerian secondary schoo students' achievement in comprehension of expository texts', Internationa Journal of Humanities and Social Science 6(6), 182-188.

Forehand, M., 2018, 'Bloom's taxonomy', in P. Lombardi (ed.), Instructional methods, strategies and technologies to meet the needs of all learners, viewed 25 February 2019, from http://granite.pressbooks.pub.

Fraenkel, J.R., Wallen, N.E. \& Hyun, H.H., 2012, How to design and evaluate research in Education, 8th edn., McGraw Hill, San Francisco, CA.

Gower, P., 2008, 'All schools need decent funding', Mail and Guardian, 9-15 May, p. 15.

Ivanitskaya, L., DuFord, S., Craig, M. \& Casey, A.M., 2008, 'How does a pre-assessment of off-campus students' information literacy affect the effectiveness of library instruction?', Journal of Library Administration 48(3-4), 509-525. https://doi. instruction?', Journal of Library
org/10.1080/01930820802289649

Jomaa, L.H., McDonnell, E. \& Probart, C., 2011, 'School feeding programs in developing countries: Impacts on children's health and educational outcomes', International Life Sciences Institute 69(2), 83-98. https://doi.org/10.1111/j.1753Life Sciences Instit

Lambert, M., 2012, A beginner's guide to doing your education research project, Sage, Los Angeles, CA.

Lee, D., 2015, 'Using questions to develop students' higher-order thinking skills: A primary English teacher's beliefs and practices', Bachelour of Education thesis, The University of Hong Kong.

Maloch, B. \& Horsey, M., 2013, 'Living inquiry: Learning from and about informational text in a second-grade classroom', The Reading Teacher 66(6), 475-485. https:// doi.org/10.1002/TRTR.1152

Mudzielwana, N.P., Joubert, I., Phatudi, N.C. \& Hartell, C.G., 2012, 'Teaching reading comprehension to Grade 3 Tshivenda-speaking learners', Journal of Educational Studies 11(1), 67-84.

Mullis, I.V.S., Martin, M.O. \& Sainsbury, M., 2016, 'Progress in international reading literacy study 2016 reading framework', International Study Center 1, 11-29.

Nam, J., 2010, 'Linking research and practice: Effective strategies for teaching vocabulary in the English Second Language classroom', Canada Journal 28(1), 127-135. https://doi.org/10.18806/tesl.v28i1.1064

Nomlomo, V., 2010, 'Classroom interaction: Turn-taking as a pedagogical strategy', A Journal for Language Learning 26(2), 50-66. https://doi.org/10.5785/26-2-21

Pilanieta, P. \& Medina, A.L. 2009, 'Reciprocal teaching for the primary grades: "We can do it, too!"', The Reading Teacher 63(2), 120-129.

Piper, B., Schroeder, L. \& Trudell, B., 2015, 'Oral reading fluency and comprehension in Kenya: Reading acquisition in a multilingual environment', Journal of Research in Reading 39(2), 1-20. https://doi.org/10.1111/1467-9817.12052

Piper, B., Zuilkowski, S.S. \& Mugenda, A., 2014, 'Improving reading outcomes in Kenya: First-year effects of the PRIMS initiative', International Journal of Educational Development 37, 11-21. https://doi.org/10.1016/j.ijedudev.2014.02.006

Pretorius, E.J. \& Currin, S., 2010, 'Do the rich get richer and poor poorer?: The effects of an intervention programme on reading in the home and school language in a high poverty multilingual context', International Journal of Educational Development 30(1), 67-76.

Pretorius, E.J. \& Klapwijk, N.M., 2016, 'Reading comprehension in South African schools: Are teachers getting it, and getting it right?', Per Linguam 32(1), 1-20. https://doi.org/10.5785/32-1-627

Pretorius, E.J. \& Spaull, N., 2016, 'Exploring relationships between oral reading fluence and reading comprehension amongst English second language readers in https://doi.org/10.1007/s11145-016-9645-9
Qannubi, M.A., Gabarre, S. \& Mirza, C., 2018, Experimenting reader's theatre to improve Omani pupils' reading motivation', Asian Journal of Language, Literature and Culture Studies $1(2), 1-11$.

Sari, M.K. \& Sari, L.R., 2019, 'The effect of anticipation guide strategy on students' reading comprehension', Journal Ta'dib 22(1), 51-55. https://doi.org/10.31958/ jt.v22i1.1434

Shukla, D. \& Dungsungnoen, A.P., 2016, 'Student's perceived level and teachers' teaching strategies of higher order thinking skills: A study on higher educational institutions in Thailand', Journal of Education and Practice 7(12), 211-219.

Sonmez, Y. \& Sulak, S.E., 2018, 'The effect of the Thinking-aloud strategy on the reading comprehension skills of 4th grade primary school students', Universal Journal of Educational Research 6(1), 168-172. https://doi.org/10.13189/ ujer.2018.060116

South Africa. Ministry of Education, 1996, Constitution of the Republic of South Africa, Government Printers, Pretoria, viewed 22 February 2021, from https://www. refworld.org/docid/3ae6b5de4.html.

South Africa. National Department of Basic Education, 2011a, National Curriculum Statement. Curriculum and Assessment Policy Statement. Foundation Phase Grades $R-3$, Government Printers, Pretoria.

South Africa. National Department of Basic Education, 2011b, National Curriculum Statement. Curriculum and Assessment Policy Statement. Foundation Phase Grades 4-6, Government Printers, Pretoria.

South Africa. National Department of Basic Education, 2011c, English home language, grades $R-3$ Foundation Phase, Government Printers, Pretoria.

South Africa. National Department of Basic Education, 2011d, Curriculum and Assessment Policy Statement (CAPS) Grades R-3, Government Printers, Pretoria.

South Africa. National Planning Commission, 2011, National development plan 2030: Our future - Make it work, Government Printers, Pretoria.

South Africa. Statistics South Africa, 2019, Quarterly financial statistics, Government Printers, Pretoria.

Taylor, N., 2014, Thinking, language and learning in Initial Teacher Education Presentation to the seminar Academic depth and rigor in ITE, University of Witwatersrand, Johannesburg.

Thompson, S., Vaughn, S., Prater, K. \& Cirino, P.T., 2004, 'The response to intervention of English language learners at risk for reading problems', Journal of Learning Disabilities 39(5), 390-398. https://doi.org/10.1177/002221940603 90050201

Vacca, R.T. \& Vacca, J.L., 2005, Content area reading, 3rd edn., Scott, Foresman and Company, London.

Van der Berg, S., Spaull, N., Wills, G., Gustafsson, M. \& Kotze, J., 2016, Identifying binding constructs in education, University of Stellenbosch, Stellenbosch, viewed 10 February 2021, from http://www.resep.sun.ac.za.

Van Eerde, H.A.A., Hajer, D.M. \& Prenger, J., 2008, 'Promoting mathematics and language learning in interaction', in D.M. Hajer \& T. Koole (eds.), Interaction in two multicultural mathematics classrooms, pp. 31-68, Aksant, Amsterdam.

Verbeek, D.C., 2010, 'Teaching reading for meaning? A case study of the initia teaching of reading in a mainstream South African school', Unpublished Doctoral thesis, University of KwaZulu-Natal, Pietermaritzburg.

Verenikina, M., 2010, 'Vygotsky in twenty-first century research', in J. Herrington \& B. Hunter (eds), Proceedings of World Conference on Educational Multimedia Hypermedia and Telecommunications, pp. 16-25, AACE, Chesapeake, VA.

Vygotsky, L.S., 1978, Mind in society: The development of higher psychological processes, Harvard University Press, Cambridge, MA.

Western Cape Education Department (WCED), 2016-2019, Reports from the Western Cape Systemic Language Results for School X, WCED, Cape Town.

World Bank Report, 2018, World Bank Report: Learning to realize education's promise, The World Bank, Washington, DC. https://doi.org/10.1596/978-14648-1096-1

Yen, T.S. \& Halili, S.H., 2015, 'Effective teaching of higher-order thinking (hot) in education', The Online Journal of Distance Education and e-Learning 3(2), 41-47. 